\title{
Uji Aktivitas Anti Bakteri Ekstrak Etanol Daun Pacar Air (Impatiens balsamina L.) terhadap Bakteri Escherichia coli
}

\author{
Hardiana $^{1^{*}}$, Yuni Dewi Safrida ${ }^{2}$, Rizki Khana Maulianda ${ }^{3}$ \\ 1,2,3 Akademi Analis Farmasi dan Makanan Banda Aceh \\ *Koresponden email: hardiana7011@gmail.com
}

Diterima: 02 Oktober 2020

Disetujui: 12 Oktober 2020

\begin{abstract}
(Impatiens balsamina L.) is an ornamental plant that has been widely developed as a medicinal plant. Secondary metabolites of water henna plant (Impatiens balsamina L.) are known to contain flavonoids. In the field of pharmacology this plant is often used because it has antibacterial agents. This study aimed to determine the inhibitory effect and the optimum antibacterial concentration of the ethanol extract of the leaves of water henna (Impatiens balsamina L.) against the growth of Escherichia coli bacteria with treatment concentrations those are $25 \%, 50 \%, 75 \%$, and $100 \%$. This research was conducted at the Akafarma Microbiology Laboratory in Banda Aceh. The method used was experimental with disk diffusion (disc method). The results showed that in repetition I and II with concentrations of $25 \%, 50$ percent, 75 percent, and 100 percent, the zone of inhibition was obtained respectively those are $23 \mathrm{~mm}$, $26 \mathrm{~mm}, 29.5 \mathrm{~mm}$, and $31 \mathrm{~mm}$. The optimum result of the ethanol extract of Impatiens balsamina L. leaves in inhibiting the growth of Escherichia coli is at the concentration of $100 \%$ with an inhibition zone diameter of $31 \mathrm{~mm}$.
\end{abstract}

Keywords: activity test, escherichia coli, ethanol extract, disk diffusion, water henna leaves,

\begin{abstract}
Abstrak
Tanaman hias Pacar air (Impatiens balsamina L.) merupakan tumbuhan yang banyak dikembangkan sebagai tanaman obat. Metabolit sekunder dari tumbuhan pacar air (Impatiens balsamina L.) diketahui mengandung flavonoid. Dibidang farmakologi tanaman ini sering digunakan karena memiliki sifat antibakteri. Tujuan penelitian untuk memahami berapa daya hambat dan konsentrasi optimum antibakteri dari ekstrak etanol daun pacar air terhadap pertumbuhan bakteri Escherichia coli dengan perlakuan konsentrasi, yaitu $25 \%, 50 \%, 75 \%$, dan $100 \%$. Metode yang digunakan yaitu eksperimental secara difusi disk (cara cakram). Hasil penelitian menunjukkan bahwa pada pengulangan I dan II untuk konsentrasi $25 \%, 50 \%, 75 \%$, dan $100 \%$ didapatkan zona hambat secara rata-rata berturut-turut, yaitu $23 \mathrm{~mm}, 26 \mathrm{~mm}$, $29,5 \mathrm{~mm}$, dan $31 \mathrm{~mm}$. Hasil optimum ekstrak etanol daun Impatiens balsamina L. dalam mencegah pertumbuhan bakteri Escherichia coli adalah dalam konsentrasi $100 \%$ dengan diameter zona hambat sebesar $31 \mathrm{~mm}$.
\end{abstract}

Kata Kunci : daun pacar air, difusi disk, escherichia coli, ekstrak etanol, uji aktifitas

\section{Pendahuluan}

Indonesia adalah negara megadiversity di dunia memiliki berbagai jenis tumbuhan yang berkhasiat sebagai obat, sehingga bisa digunakan untuk mengobati penyakit. Dalam pengobatan tradisional, umumnya memakai racikan dari tumbuhan, baik berupa daun, bunga, biji, buah, batang, dan akar. Hal ini dilakukan karena tumbuhan mengandung metabolit sekunder yang memiliki potensi seperti antioksidan, antibiotik, antikanker, dan dapat menghambat efek karsinogenik [1]. Kemampuan meracik tumbuhan yang berkhasiat sebagai obat biasanya didapatkan secara turun temurun berdasarkan pengalaman (kearifan lokal). Di Indonesia banyak menggunakan tanaman herbal yang bermanfaat sebagai obat tradisional dalam pengobatan alternatif. Beberapa dari jenis tanaman dapat dimanfaatkan sebagai obat alternatif, salah satu jenis tanaman tersebut yaitu Impatiens balsamina L. atau dalam bahasa daerah dikenal dengan sebutan pacar air.

Impatiens balsamina L. awalnya merupakan tumbuhan hias [2]. Namun seiring perkembangan zaman, tanaman pacar air mulai dikenal luas sebagai ramuan obat dan banyak digunakan sebagai obat herbal di seluruh dunia [3]. Tanaman ini secara tradisional digunakan untuk mengobati luka duri atau tusukan kaca, abses [4], skrofulosis, bisul, disentri [5], rematik, nyeri otot dan tulang, patah tulang, infeksi superfisial, radang kuku [6], tumor, persalinan yang sulit, dan nyeri nifas [7]. 
Menurut ref. [8] daun pacar air memiliki kandungan flavonoid, saponin, kuinon, steroid dan tanin yang merupakan metabolit sekunder dari tanaman tersebut. Metabolit sekunder tersebut bersifat sebagai anti bakteri. Ref. [9,10] juga melaporkan bahwa flavonoid merupakan senyawa polifenol yang umum terkandung dalam tumbuhan dalam jumlah yang signifikan. Berbagai penelitian telah menunjukkan bahwa flavonoid dalam tumbuhan memiliki efek yang berpotensi menguntungkan sebagai agen antimikroba [9]. Sementara itu, pacar air mengandung senyawa aktif antimikroba, yaitu antioksidan, antidiabetes, antiinflamasi, antibakteri, antijamur, antivirus, dan antikanker yang berfungsi untuk mencegah pertumbuhan bakteri. Di dalam dunia medis, penggunaan senyawa antibakteria adalah sebagai obat dalam penyembuhan berbagai jenis penyakit infeksi oleh bakteri pathogen.

Escherichia coli adalah anaerob fakultatif yang dominan dari flora kolon manusia [11,12] dan merupakan jenis bakteri gram negatif fakultatif anaerobik yang mempunyai alat gerak berupa flagel [13]. Tiga sindrom klinis yang umum terjadi akibat infeksi strain Escherichia coli yang bersifat pathogen, yaitu infeksi saluran kemih, sepsis / meningitis, gagal ginjal akut, dan penyakit enterik / diare [14-16]. Di bidang farmakologi banyak dilakukan penelitian untuk menemukan antibiotik dari berbagai jenis tumbuhan yang berkhasiat obat karena cenderung lebih aman untuk dikonsumsi tubuh dibandingan obat sintetik. Penggunaan antibiotik sintetik dalam jangka panjang dapat menyebabkan resistensi mikroba terhadap antibiotik dan juga dapat menyebabkan efek samping pada host seperti hipersensitivitas, penipisan mikroorganisme mukosa dan usus, dan reaksi alergi [17]. Oleh karena itu pentingnya penggalian sumber antimikroba dari bahan alam [18].

Ref. [19] melaporkan bahwa ekstrak etanol dari bunga pacar air mampu menghalangi perkembangan bakteri Escherichia coli dengan berbagai konsentrasi, yaitu 10 persen, 20 persen, 40 persen, dan 80 persen diperoleh zona hambat berturut-turut $7,83 \mathrm{~mm} ; 10,16 \mathrm{~mm} ; 14,00 \mathrm{~mm}$; dan 19,00 $\mathrm{mm}$. Sementara itu, pada biji dengan konsentrasi yang sama diperoleh zona hambat yaitu 3,66 mm; 5,16 $\mathrm{mm} ; 6,66 \mathrm{~mm}$; dan 8,33 mm. Penelitian yang dilakukan oleh Ref. [20] menyatakan bahwa efektivitas dari pemberian ekstrak etanol daun pacar air dalam mencegah pertumbuhan bakteri Candida albicans pada konsentrasi 25\%,50\%,75\%, dan 100\% diperoleh zona hambat, yaitu 8,66 mm; 11,66 mm; 13,66 mm; dan 6,00 mm. Menurut ref. [21] semakin besar konsentrasi ekstrak etanol daun pacar air yang diberikan maka akan meningkatkan rata-rata diameter zona hambat pada perkembangan bakteri. Karenanya, penting dilakukan penelitian untuk menyelidiki kemampuan senyawa aktif yang terkandung di dalam ekstrak daun pacar air dalam menghalangi perkembangan bakteri Escherichia coli.

\section{Metode Penelitian}

Penelitian ini dilakukan di Laboratorium Mikrobiologi, Akademi Analis Farmasi dan Makanan (Akafarma) Banda Aceh. Riset ini telah dilaksanakan dari bulan Juni sampai dengan bulan Juli 2020.

Alat dan bahan yang dipakai dalam riset ini adalah cawan petri, pipet tetes, Erlenmeyer, tabung reaksi, rak tabung, gelas kimia, jarum ose, gelas ukur, penangas air, timbangan analitis, batang pengaduk, blender, labu ekstraksi, rotary evaporator, pinset, corong kaca, autoklaf, mistar, lampu spiritus, kertas cakram, aluminium foil, pinset, ayakan mesh 200, daun pacar air (Impatiens balsamina L.), bakteri uji (Escherichia coli) yang diperoleh dari laboratorium pengujian mikrobiologi, etanol, aquades, antibiotik (Amoxilin $500 \mathrm{mg}$ ), media Mueller hinton agar (MHA), media NB, kertas saring no. 1, kapas, dan kertas label. Riset ini memakai metode eksperimental laboratorium secara difusi disk dengan berbagai perlakukan konsentrasi larutan yaitu 25\%, 50\%, 75\%, dan $100 \%$.

\section{Prosedur Kerja \\ a. Persiapan sampel}

Daun pacar air yang masih segar dikumpulkan dan dicuci menggunakan air mengalir hingga bersih. Selanjutnya, daun ditiriskan dan dikering anginkan. Kemudian dihaluskan dan diayak sampai menjadi serbuk.

\section{b. Pembuatan Ekstrak Sampel}

Sebanyak 100 gram serbuk daun acar air yang telah ditimbang ditempatkan pada wadah kaca. Lalu direndam dalam etanol $96 \%$ sebanyak $500 \mathrm{~mL}$ selama 48 jam dan ditutup. Kemudian disaring memakai corong yang telah dilapisi kertas saring untuk memisahkan antara residu dan sari. Kemudian ditambahkan larutan etanol 96\% sebanyak $500 \mathrm{~mL}$ kedalam residu tersebut dan dibiarkan selama 48 jam dalam keadaan tertutup, namun sesekali perlu diaduk. Setelah \pm 48 jam, sampel tersebut disaring sampai menghasilkan dua filtrat dan dua ampas. Kemudian filtrat pertama dan filtrat kedua dicampur dan dipekatkan menggunakan rotary evaporator, sehingga didapatkan ekstrak daun pacar air dalam konsistensi yang kental [22]. 


\section{c. Sterilisasi Alat}

Seluruh peralatan kaca yang dipakai pada riset seperti cawan petri, gelas kimia, labu ukur, Erlenmeyer, tabung reaksi, corong kaca, dan pipet ukur dibungkus dengan kertas buram. Selanjutnya disterilisasi dalam autoklaf selama 30 menit dengan temperatur $121^{\circ} \mathrm{C}$. Sementara itu, batang bengkok dan ose bulat disterilkan menggunakan bunsen.

\section{d. Pembuatan Larutan Kontrol negatif}

Disiapkan larutan aquades steril (50 ML) untuk dijadikan kontrol negatif sebagai pembanding dan pembuatan larutan uji.

\section{e. Pembuatan Larutan Kontrol Positif}

Digerus satu tablet obat Amoxilin $500 \mathrm{mg}$, lalu ditimbang sebanyak $50 \mathrm{mg}$. Kemudian tablet yang sudah dalam bentuk powder ditambahkan $50 \mathrm{~mL}$ aquades steril. Selanjutnya sebanyak $1 \mathrm{~mL}$ larutan tersebut diambil, lalu ditambahkan aquades sampai $10 \mathrm{~mL}$ dan didapat larutan Amoxilin sebesar $5 \mu \mathrm{g} / 50 \mu \mathrm{L}$.

\section{f. Pembuatan Larutan Uji}

Ditimbang ekstrak etanol daun pacar air sebesar 0,$5 ; 1 ; 1,5$ dan 2 (gram). Kemudian pada masingmasing ekstrak ditambahkan $2 \mathrm{~mL}$ larutan aquades steril. Sehingga diperoleh larutan uji dengan konsentrasi tertentu $(25 \%, 50 \%, 75 \%$, dan $100 \%)$.

\section{g. Pembuatan Media}

Ditimbang sebanyak 1,3 gram media NB dan ditempatkan ke dalam Erlenmeyer, ditambahkan 10 $\mathrm{ml}$ aquades. Larutan dipanaskan hingga menjadi larutan yang homogen, lalu disterilisasi dengan autoklaf. Sementara itu, media Mueller Hinton Agar (MHA) juga ditimbang sejumlah 3,8 gram dan dimasukkan ke erlenmeyer, selanjutnya dimasukkan aquades steril sebanyak $100 \mathrm{ml}$. Dipanaskan hingga homogen, lalu disterilkan dengan autoklaf.

\section{h. Peremajaan Bakteri}

Diambil 1 koloni bakteri Escherichia coli dan dimasukkan kedalam tabung reaksi yang berisi media NB dan larutkan menggunakan ose bulat. Koloni diinkubasi dengan suhu ruang $\left(37^{\circ} \mathrm{C}\right)$ selama 24 jam.

\section{i.Uji Aktifitas Ekstrak Daun Pacar Air Terhadap Escherichia coli}

Sebanyak $1 \mathrm{~mL}$ suspensi Escherichia coli dipipet ke dalam media MHA dengan cara spread plate dan biarkan selama 3 menit sampai suspensi bakteri meresap kedalam media. Diletakkan 1 disk antibiotik, 2 disk blank (25\%, 50\%, 70\%, dan 100\%) dan disk blank kontrol negatif pada permukaan media MHA secara aseptik. Diinokulasi setiap paper disk dengan memperhatikan jarak agar tidak terjadi overlapping zona hambat. Diberi label nama pada dasar cawan petri dan diinkubasi 48 jam. Selanjutnya diameter zona jernih yang terbentuk disekitar paper disk diukur memakai jangka sorong.

\section{j. Pengamatan dan Pengukuran}

Pengukuran zona hambat terhadap pertumbuhan bakteri disekitar kertas cakram dilakukan setelah 24 jam menggunakan jangka sorong. Cawan petri dibalik agar mempermudah untuk melihat daerah hambatan yang transparan disekitar kertas cakram. Hasil negatif ditunjukkan jika disekitar kertas cakram tidak terdapat zona jernih. Sementara itu, hasil positif ditunjukkan jika disekitar kertas cakram terdapat zona jernih yang merupakan zona tidak ditumbuhi bakteri.

\section{Hasil dan Pembahasan}

Hasil riset terhadap uji aktifitas antibakteri dari ekstrak etanol daun pacar air terhadap pertumbuhan bakteri Escherichia coli dapat dilihat pada Tabel 1.

Tabel 1. Rata-rata diameter zona hambat dari ekstrak etanol daun pacar air (Impatiens balsamina L.) terhadap perkembangan bakteri Escherichia coli

\begin{tabular}{cccc}
\hline Konsentrasi (\%) Ekstrak Daun & \multicolumn{2}{c}{ Diameter Zona Hambat } & Pengulangan \\
Pacar Air & I & II & Rata-rata (mm) \\
\hline $25 \%$ & 23 & 23 & 23 \\
$50 \%$ & 24 & 28 & 26 \\
$75 \%$ & 30 & 29 & 29,5 \\
$100 \%$ & 31 & 31 & 31 \\
Aquadest (-) & 0 & 0 & 0 \\
Amoxicilin (+) & 30 & 37 & 33,5 \\
\hline
\end{tabular}

Sumber: Hasil penelitian (2020) 
Berdasarkan Tabel 1, pengukuran rata-rata diameter zona hambat dari ekstrak etanol daun pacar air menunjukkan hasil, yaitu 25 persen $(23 \mathrm{~mm}), 50$ persen $(26 \mathrm{~mm}), 75$ persen $(29,5 \mathrm{~mm})$, dan 100 persen $(31 \mathrm{~mm})$. Zona hambat terbentuk disekeliling kertas cakram yang ditandai warna bening. Zona bening yang terbentuk tersebut diasumsikan bahwa esktrak etanol dari daun pacar air berhasil dalam menghambat pertumbuhan patogen Escherichia coli. Variasi perlakukan konsentrasi yang digunakan dari konsentrasi terendah hingga konsentrasi tertinggi untuk melihat seberapa besar efekstifitas dari esktrak tersebut.

Konsentrasi $100 \%$ yang digunakan dalam penelitian ini merupakan konsentrasi optimum dalam menghalangi perkembangan patogen. Hal ini sesuai dengan ref. [23] yang melaporkan bahwa ekstrak etanol dari Impatiens balsamina L. menunjukkan aktivitas antimikroba yang cukup tinggi terhadap Escherichia coli dan Candida albicans. Hasil pembentukan zona hambat dari ekstrak etanol daun pacar air terhadap Escherichia coli tampak pada Gambar 1.

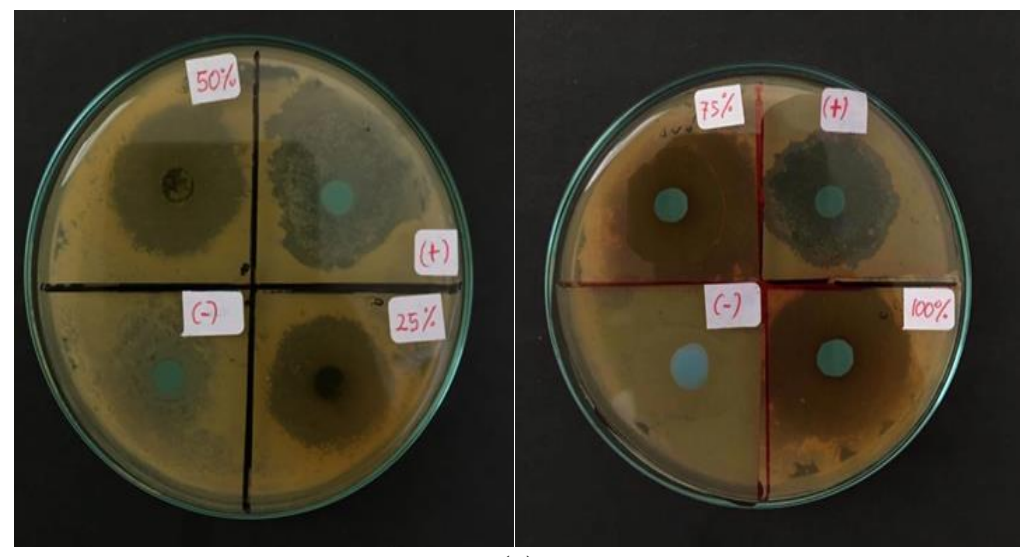

(a)

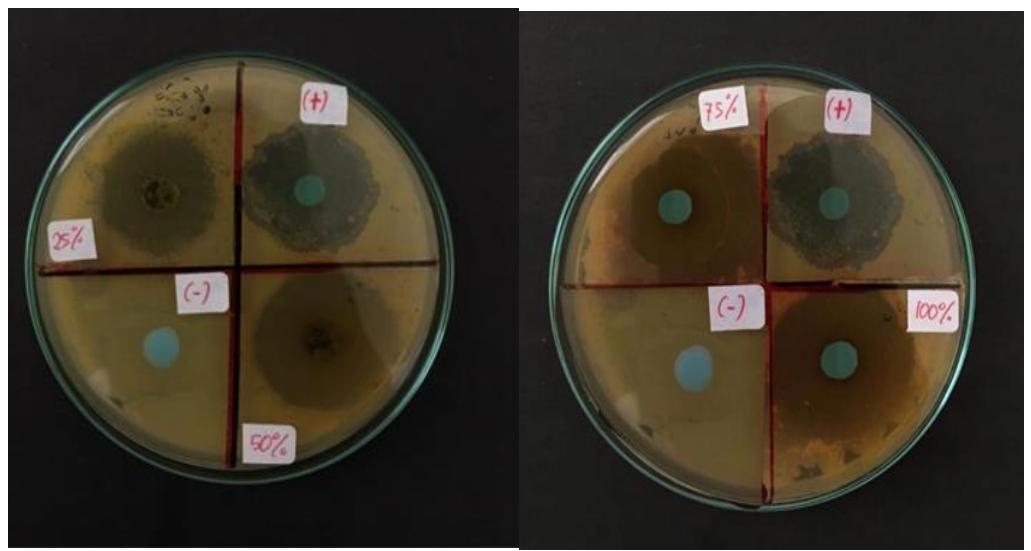

(b)

Gambar 1. Zona hambat yang terbentuk dari ekstrak etanol daun pacar air (Impatiens balsamina L.) terhadap pertumbuhan bakteri Escherichia coli; (a) Pengulangan 1 dan (b) Pengulangan 2

Sumber: Hasil penelitian (2020)

Berdasarkan Gambar 1 terlihat bahwa terbentuk zona hambat bakteri E. coli pada seluruh perlakuan, yaitu pada konsentrasi 25\%, 50\%, 75\%, dan 100\%. Ini terlihat dari munculnya zona bening yang terbentuk disekeliling kertas cakram. Berdasarkan Ref. [24] respons hambatan pertumbuhan menunjukkan bahwa terdapat beberapa kategori zona hambat, yaitu zona hambat $<20 \mathrm{~mm}$ (sangat kuat), 10-20 mm (kuat), 5-10 mm (sedang), dan $>5 \mathrm{~mm}$ (lemah). Berdasarkan hal tersebut uji aktifitas antibakteri ekstrak etanol daun pacar air terhadap patogen Escherichia coli pada konsentrasi 25 persen $(23 \mathrm{~mm}), 50$ persen $(26 \mathrm{~mm}), 75$ persen $(29,5)$, dan 100 persen $(31 \mathrm{~mm})$, dapat dikategorikan mempunyai daya antibakteri sangat kuat. Namun demikian, efektifitas tertinggi zona hambat yang terbentuk ditunjukkan pada konsentrasi 100 persen $(31 \mathrm{~mm})$. Hal tersebut sesuai dengan Ref. [19], bahwa zona hambat yang didapat, yaitu 7,83 mm (10\%), 10,16 mm (20\%), 14,00 mm (40\%), dan 19,00 mm (80\%) yang dilakukan pada bunga, sedangkan pada biji dengan konsentrasi yang sama zona hambat yang didapat, yaitu 3,66 mm, 5,16 mm, 6,66 mm, dan 8,33 mm. Ref. [20] juga melaporkan bahwa ekstrak etanol daun pacar air mampu menghambat pertumbuhan Candida albicans dengan konsentrasi 25, 50, 75, 
dan $100(\%)$ dan diameter zona hambat berturut-tutut sebesar 8,66 mm, 11,66 mm, 13,66 mm, dan 6,00 $\mathrm{mm}$.

Menurut ref. [25] tumbuhan memiliki kemampuan yang hebat dalam menghasilkan metabolit sekunder seperti fenolat dan polifenol, alkaloid, terpenoid dan minyak atsiri, lektin, dan lain-lain. Hal yang sama dilaporkan oleh ref $[8,26]$, zona hambat bakteri yang terbentuk pada medium karena adanya metabolit sekunder yang dimiliki daun pacar air seperti alkaloid, flavonoid, tanin, saponin, kuinon, dan fenol yang bersifat sebagai antibakteri.

Flavonoid dapat berfungsi sebagai antibakteri, antiinflamasi, antialergi, antimutagenik, antivirus, antitrombotik, dan vasodilatasi. Kehadiran senyawa flavonoid di dalam tanaman dapat membantu aktivitas antibakteri tanaman [27], salah satunya tanaman pacar air. Perlakuan antibakteri flavonoid melalui beberapa cara yaitu membunuh bakteri secara langsung, mengurangi patogenisitas bakteri dan mensinergiskan antibiotik [28]. Aktivitas antibakteri flavonoid bergantung pada strukturnya yaitu pada substitusi cincin aromatik. Pengujian ekstrak tumbuhan dengan aktivitas antibakteri yang banyak dilakukan, semakin banyak flavonoid yang terbukti efektif sebagai agen antibakteri [29].

Daun pacar air yang dipakai pada penelitian ini diekstraksi sebanyak 100 gram dan hasil ekstrak diperoleh 8 gram ekstrak kental, dengan ciri-ciri fisik, yaitu berwarna hitam dengan aroma khas daun pacar air. Hasil zona hambat yang didapatkan dari daun pacar air cenderung sangat kuat karena banyaknya zat aktif yang terkandung [21]. Penggunaan amoxicilin sebagai kontrol positif karena Amoxicilin merupakan antibiotik golongan Penicilin dengan cara membunuh dan menghentikan bakteri untuk berkembang biak di dalam tubuh, terutama yang disebabkan oleh bakteri gram negatif. Sementara itu, kontrol negatif menggunakan aquades steril untuk melihat pengaruh pelarut terhadap pertumbuhan Escherichia coli, juga sebagai pelarut ekstrak dalam sampel.

\section{Kesimpulan}

Hasil riset menunjukkan bahwa ekstrak etanol daun pacar air air (Impatiens balsamina L.) efektif sebagai agen antibakteri untuk menghalangi perkembangan bakteri Escherichia coli pada semua konsentrasi. Hasil optimum ekstrak etanol daun Impatiens balsamina L. dalam menghambat pertumbuhan bakteri Escherichia coli adalah pada konsentrasi 100 persen dengan diameter zona hambat sebesar 31 $\mathrm{mm}$.

\section{Ucapan Terima Kasih}

Author berterima kasih banyak kepada Akademi Analis Farmasi dan Makanan (Akafarma) Banda Aceh, keluarga, dan rekan-rekan sejawat yang telah banyak mendukung dan memberi bantuan kepada author dalam menyelesaikan penelitian ini.

\section{Saran}

Diharapkan untuk penelitian selanjutnya agar dapat meneliti bakteri lainnya seperti Salmonella Enterica dan juga menguji bakteri Escherichia coli dengan identifikasi lengkap.

\section{Referensi}

[1] J. Yuhernita, "Analisa Senyawa Metabolit Sekunder dari Ekstrak Metanol Daun Surian Yang berpotensi Sebagai Antioksidan," Makara Sains,vol. 15, hal. 48-52, 2011.

[2] Adfa, "Senyawa Antibakteri Dari Daun Pacar air (Impatiens Balsamica L.)," Jurusan Kimia, Fakultas Matematika dan Ilmu Pengetahuan Alam, Universitas Bengkulu, Indonesia,Vol. 4(1), hal. 318-322, 2001.

[3] Gaby, "Bioaktifitas Ekstrak Metanol daun Pacar air (Impatiens BalsamicaL) terhadap Pertumbuhan bakteri Staphylococcus aureus Dan Pseudomonas Aeruginosa Penyebab Cantengan," Skripsi. Fakultas Matematika dan Ilmu Pengetahuan Alam, Universitas Hasanuddin Makassar, 2007.

[4] A. Sakunphueak, P. Panichayupakaranant, "Comparison of antimicrobial activities of naphthoquinones from Impatiens balsamina," Nat. Prod, vol. 26, pp. 1119-1124, 2012.

[5] S.C. Kang, \& Y. Moon, "Isolation and antimicrobial activity of a naphthoquinone from Impatiens balsamina," J. Pharmacogn, vol. 23, pp. 240-247, 1992.

[6] Jiangsu New Medical College, The Dictionary of Chinese Herbal Medicines, Shanghai Science and Technology Publisher, Shanghai, China, pp. 278-346, 1984.

[7] X. Yang, D. K. Summerhurst, S. F. Koval, C. Ficker, F. L. Smith, and M. A. Bernards, Isolation of an antimicrobial compound from Impatiens balsamina L. using bioassay-guided fractionation, Phytother, Res. 15, pp. 676-689, 2001. 
[8] R. Almira, "Kajian Aktivitas Fraksi Hexsan Rimpang Kunyit (Curcuma longa Linn) Terhadap Proses Persembuhan Luka Pada Mencit (Musmusculus Albinus),"Skripsi, FKH IPB, Bogor, 2008.

[9] Y. Mustapha \& S. Hafsat, "Antibacterial Activities of Anacardium occidentale (L.) Leaf Extract Against Some Selected Bacterial Isolates," International Journal of Pure and Applied Science, vol. 1 (1), pp. 40-43, 2007.

[10] G. Gutiérrez-Venegas, Z. González-Rosas, “Apigenin reduce lipoteichoic acid-induced inflammatory response in rat cardiomyoblast cells," Arch Pharm. Res, vol. 40(2), pp. 240-249, 2017.

[11] B. S. Drasar \& M. J. Hill, Human intestinal flora, Academic Press, United Kingdom, London, Ltd, pp. 36-43, 1974.

[12] E. Jawetz, Mikrobiologi Kedokteran, Edisi Kedua puluh, EGC, Jakarta, hal, 239-240, 259, 2001.

[13] Ikmalia, "Analisa Profil Protein Isolat Escherichia coli S1 Hasil Iradiasi Sinar Gamma," Skripsi, Fakultas sains dan Teknologi, Universitas Islam Negeri Syarif Hidayatullah Jakarta, 2008.

[14] James P. Nataro and James B. Kaper, "Diarrhea genic Escherichia coli," Clin Microbiol, vol. 11(1), pp. 142-201, 1998.

[15] R. Maksum, Buku Ajar Mikrobiologi, EGC, Jakarta, Hal 179-185, 2020.

[16] SF. Antung, 2009. "Evaluasi Bakteri Indikator Sanitasi,” Diakses pada Tanggal 09 Oktober 2020 di http://web.ipb.ac.id/ Ippm/ID/index.php? view=jurnal/detail2JIPI\&volume=11\&no=2\&id=91, 2009.

[17] A. Lopez, J. B. Hudson and G. H. N. Towers, "Antiviral and antimicrobial activities of Colombian medicinal paints," Journal of Ethnopharmacology, 77: 189-96, 2001.

[18] Sari dan Rafika, "Aktivitas Antibakteri Minyak Atsiri Kulit Jeruk Pontianak Terhadap Staphylococcus aureus dan Escherichia coli," J. Penelitian Pharmacy Department, Faculty of Medicine, Universitas Tanjungpura, Pontianak, vol. 18(2), hal.121-126, 2013.

[19] S. M. A. Budiana, N. S. Kojong, dan S.D. Wewengkang, "Uji aktivitas ekstrak etanol tanaman Pacar Air (Impatiens Balsamica L.) terhadap pertumbuhan bakteri Staphylococcus aureus, Pseudomonas aeruginosa dan Escherichia coli secara in vitro," J. Ilmiah Farmasi UNSRAT, vol. 4 (4), hal. 214-223, 2014.

[20] N. Naitullah, F. Jamin, Frengki, dan M. Dewi, "Pengaruh Ekstrak Etanol Daun Pacar Air (Impatiens balsamica L.) Terhadap Pertumbuhan Candida albicans Secara In Vitro," J. Medika Veterinaria, Fakultas Kedokteran Hewan, Unsyiah, 8 (2) : 125-127, 2014.

[21] S.F. Kusuma, S. M. Widyastuti, dan B. Fajar, "Uji aktivitas ekstrak etanol sirih merah terhadap Trichomonas vaginalis," J. Universitas Padjajaran, vol. 115, hal. 11-14, 2009.

[22] Departemen Kesehatan RI, Sediaan Galenik, Departemen Kesehatan RI, Jakarta, 1986.

[23] Suk-Nam Kang, Young-Min Goo, Mi-Ra Yang, Rashid Ismael Hag Ibrahim, Jae-Hyeon Cho, IlSuk Kim, and Ok-Hwan Lee, "Antioxidant and Antimicrobial Activities of Ethanol Extract from the Stem and Leaf of Impatiens balsamina L. (Balsaminaceae) at Different Harvest Times," Molecules, vol. 18, pp. 6356-6365, 2015.

[24] G. P. Morales, A. Sierra, L. Parades, Loyola, Gallardo, and Borquez, "Secondary Metabolites from four Medical Plants from Northern Chile Antimicrobial Activity and Biotoxicity Agaist Artemia salina," J . chile Chem, 48:2, 2003.

[25] L. Othman, A. Sleiman, and R. M. Abdel-Massih, Antimicrobial Activity of Polyphenols and Alkaloids in Middle Eastern Plants, 2019, Diakses pada Tanggal 7 Oktober 2020 di https://www.frontiersin.org/articles/10.3389/fmicb.2019.00911/full

[26] O. O. Temitope and A. Ayodele, "Antimicrobial, Phytochemical and Proximate Analysis of Four Nigerian Medicinal Plants on some Clinical Microorganisms," Current Research in Microbiology and Biotechnology, vol. 2 (5), pp. 457-461, 2015.

[27] Ji - Ae Shin, M. H. Ryu, Ki - Han Kwon, B. Young, Choi, Sung - Dee Cho, "Down-regulation of Akt by methanol extracts of Impatients balsamina L. promotes apoptosis in human oral squamous cell carcinoma cell lines," J. of oral pathology and Medicine, vol. 44(6), pp. 420-428, 2015.

[28] T. P. T. Cushnie \& A. J. Lamb, "Recent advances in understanding the antibacterial properties of flavonoids," Int. J. Antimicrob. Agents, vol. 38(2), pp. 99-107, 2011.

[29] E. P. Gutiérrez-Grijalva, M. A. Picos-Salas, N. Leyva-López, M. S. Criollo-Mendoza, G. VazquezOlivo, and J. B. Heredia, "Flavonoids and phenolic acids from oregano: Occurrence, biological activity and health benefits," Plants, vol. 7, pp. 2, 2018. 